\section{Case Reports in Gastroenterology}

Case Rep Gastroenterol 2017;11:369-376

DOI: $10.1159 / 000462965$

Publisned onime: June $y, 2017$
(C) 2017 The Author(s)

Published by S. Karger AG, Basel www.karger.com/crg

This article is licensed under the Creative Commons Attribution-NonCommercial 4.0 International License (CC BY-NC) (http://www.karger.com/Services/OpenAccessLicense). Usage and distribution for commercial purposes requires written permission.

\title{
A Hepatitis C Virus-Associated Cirrhotic Patient Developing Interstitial Pneumonia during the Course of Antiviral Therapy with Ombitasvir/Paritaprevir/Ritonavir
}

\author{
Kazuo Tarao ${ }^{a}$ Kouzo Yamada ${ }^{b}$ \\ ${ }^{a}$ Tarao's Gastroenterological Clinic, Yokohama, Japan; ${ }^{b}$ Department of Thoracic Oncology, \\ Kanagawa Cancer Center, Yokohama, Japan
}

\section{Keywords}

Hepatitis C virus liver disease · Ombitasvir/paritaprevir/ritonavir · Interstitial pneumonia ·

Direct-acting antivirals · Dry cough

\begin{abstract}
Oral direct-acting antivirals (DAAs) are the main therapy for hepatitis C virus (HCV)associated liver disease in Japan. Daclatasvir/asunaprevir is the first agent and sofosbuvir/ledipasvir is the secondary agent for HCV genotype 1b. More recently, ombitasvir/paritaprevir/ritonavir is also recommended as a potent therapy for HCV genotype $1 \mathrm{~b}$. Among the adverse events associated with these oral DAAs, interstitial pneumonia is one of the most severe ones. Regarding treatment with daclatasvir plus asunaprevir or sofosbuvir plus ledipasvir, a few cases have already been reported in a postmarketing surveillance. Recently, we have encountered a HCV-associated genotype $1 \mathrm{~b}$ cirrhosis patient who developed interstitial pneumonia during treatment with ombitasvir/paritaprevir/ritonavir and who recovered after drug discontinuation without corticosteroid therapy. Interstitial pneumonia was
\end{abstract}

Taiyo Building, 2-58-6, Futamatagawa, Asahi-ku

Yokohama, Kanagawa (Japan)

E-Mail nrg18449@nifty.com 


\section{Case Reports in \\ Gastroenterology}

Case Rep Gastroenterol 2017;11:369-376

(c) 2017 The Author(s). Published by S. Karger AG, Basel www.karger.com/crg

Tarao and Yamada: An HCV-Associated Cirrhotic Patient Developing Interstitial

Pneumonia during Antiviral Therapy with Ombitasvir/Paritaprevir/Ritonavir

confirmed by chest $\mathrm{x}$-ray and chest computed tomography. The serum KL- 6 level was elevated to $1,180 \mathrm{U} / \mathrm{mL}$. The total duration of the drug administration was 7 weeks, and she achieved SVR 24 . This is the first detailed report in the literature on the development of interstitial pneumonia during treatment with ombitasvir/paritaprevir/ritonavir. When dry cough appeared in the treatment with DAAs, chest computed tomography and the evaluation of serum KL-6 level were recommended.

(C) 2017 The Author(s)

Published by S. Karger AG, Basel

\section{Introduction}

Antiviral therapy using oral direct-acting antivirals (DAAs) has recently become the main and most effective therapy for eradicating hepatitis C virus (HCV) in Japan. Daclatasvir/asunaprevir is the first [1,2] and sofosbuvir/ledispasvir is the second agent [3, 4]. More recently, ombitasvir/paritaprevir/ritonavir is also used for eradicating HCV in HCVassociated chronic hepatitis and liver cirrhosis of Child stage A [5, 6]. However, these drugs have some adverse events including lung diseases. In general, among the lung diseases induced by drugs, interstitial pneumonia is the most frequent one $[7,8]$.

We have recently encountered an HCV-associated cirrhotic patient who developed interstitial pneumonia during the administration of ombitasvir/paritaprevir/ritonavir. However, there are no detailed reports in the literature on interstitial pneumonia caused by oral DAAs, including ombitasvir/paritaprevir/ritonavir.

\section{Case Report}

A 77-year-old Japanese female (height $152.1 \mathrm{~cm}$; weight $55.0 \mathrm{~kg}$ ) with $\mathrm{HCV}$-associated cirrhosis (genotype 1b) visited our clinic for treatment with oral DAAs. The patient had a history of HCV-associated chronic hepatitis in her 50s caused by blood transfusion to treat bleeding from a duodenal ulcer. Four months after the transfusion, she felt malaise, which lasted for 1 week. However, no therapy was performed. When she was 55 years old, her general practitioner diagnosed a gradual elevation of serum aspartate aminotransferase (AST) and serum alanine aminotransferase (ALT). The peak of ALT reached more than $100 \mathrm{IU} / \mathrm{mL}$. Thereafter, she was treated with oral ursodeoxycholic acid (300 mg/day). It was confirmed that HCV antibody was positive. She did not receive IFN therapy (including PegIFN/ribavirin therapy).

This was her first IFN-free DAA treatment which is a standard therapy available in Japan for chronic HCV infection.

Table 1 shows the laboratory data at the beginning of the therapy. The abnormal data were as follows: PT activity was $70.1 \%$, serum albumin level was $3.3 \mathrm{~g} / \mathrm{dL}$, serum aspartate transaminase was $101 \mathrm{U} / \mathrm{L}$, serum alanine transaminase was $50 \mathrm{U} / \mathrm{L}$, alkaline phosphatase was $419 \mathrm{U} / \mathrm{L}, \gamma$-glutamyl transpeptidase was $68 \mathrm{U} / \mathrm{L}$, total cholesterol was $122 \mathrm{mg} / \mathrm{dL}$, HCVRNA was $6.5 \log \mathrm{IU} / \mathrm{ml}$ of the viral load (real-time PCR), $\alpha$-fetoprotein was $13.4 \mathrm{ng} / \mathrm{ml}$, and the Child-Pugh score $[9,10]$ was 6 points. HCV was $1 \mathrm{~b}$ type and HCV genomic deviation in $\mathrm{Y} 93 \mathrm{H}$ was $3 \%$. Abdominal ultrasonography and computed tomography revealed enlarge- 


\section{Case Reports in Gastroenterology} \begin{tabular}{l|l}
\hline Case Rep Gastroenterol 2017;11:369-376 \\
\hline DOI: $10.1159 / 000462965$ & $\begin{array}{l}\text { @ 2017 The Author(s). Published by S. Karger AG, Basel } \\
\text { www.karger.com/crg }\end{array}$ \\
\hline
\end{tabular}

Tarao and Yamada: An HCV-Associated Cirrhotic Patient Developing Interstitial

Pneumonia during Antiviral Therapy with Ombitasvir/Paritaprevir/Ritonavir

ment of the left hepatic lobe and an irregular liver surface, and the patient was diagnosed with liver cirrhosis.

Ombitasvir $25 \mathrm{mg} /$ paritaprevir $150 \mathrm{mg} /$ ritonavir $100 \mathrm{mg}[5,6]$ was administered once a day from May 22, 2016. On June 13, the patient felt a sensation of fatigue. HCV-RNA was reduced gradually and became undetectable on July 17 (at 4 weeks of treatment). On July 18, dry cough appeared and lasted for 10 days. However, she had no fever throughout the course.

A chest $\mathrm{x}$-ray 10 days after the onset of dry cough showed a ground-glass density in the lower part of the bilateral lungs (Fig. 1a), which had almost disappeared at 4 weeks after stopping the administration of ombitasvir/paritaprevir/ritonavir (Fig. 1b).

Chest computed tomography [11] showed typical features of interstitial pneumonia in the lower part of both lungs 18 days after the beginning of dry cough in both coronary and sagittal slices (Fig. 2). Lung function tests including vital capacity were all within the normal ranges. $\mathrm{O}_{2}$ saturation was $98 \%$. Additionally, serum KL-6 levels [12] were elevated to 1,036 and $1,180 \mathrm{U} / \mathrm{mL}$ on July 12 and 15 , respectively (Table 1 ).

On July 8, the drugs were discontinued (the duration of administration was 7 weeks). The dry cough disappeared gradually and fully resolved. Chest computed tomography on August 19 (70 days after discontinuation of ombitasvir/paritaprevir/ritonavir) showed the almost complete resolution of the interstitial pneumonia (Fig. 3). In this case, interstitial pneumonia resolved spontaneously without steroid treatment.

\section{Discussion}

Oral DAAs are now the main therapy for HCV-associated liver disease in Japan. Daclatasvir/asunaprevir is the first agent $[1,2]$, and sofosbuvir/ledipasvir is the secondary one $[3,4]$. Recently, ombitasvir/paritaprevir/ritonavir has also been recommended for HCV genotype $1 \mathrm{~b}$ infection $[5,6]$. However, there are some adverse events associated with these oral DAAs, including interstitial pneumonia.

Fifteen patients have been reported in Japan who developed interstitial pneumonia caused by oral DAAs (Table 2): 4 cases due to asunaprevir/daclatasvir [13], 5 cases due to sofosbuvir/ledipasvir [14], 2 cases due to sofosbuvir/ribavirin, and 4 cases due to ombitasvir/paritaprevir/ritonavir, including our present case [15]. The incidence of interstitial pneumonia caused by oral DAAs is low: $0.002 \%$ with asunaprevir/daclatasvir, $0.0012 \%$ with sofosbuvir/ledipasvir, and $0.0095 \%$ with ombitasvir/paritaprevir/ritonavir [13-15]. Except 4 cases associated with asunaprevir/daclatasvir, there is a fatal case in each of these groups (Table 2). Dry cough was the first symptom in almost all of these cases.

The age distribution was advanced: all 4 patients with the events associated with asunaprevir/daclatasvir were over 70 years old, and the majority of patients with severe adverse events including interstitial pneumonia caused by sofosbuvir/ledipasvir were over 76 years old. One younger patient with the event associated with sofosbuvir/ledipasvir, who was 54 years old, had a past history of interstitial pneumonia [14]. Although there have been no comprehensive reports of patients with the events caused by ombitasvir/paritaprevir/ritonavir, our patient was 77 years old. 
Chest computed tomography, which was the main examination for the diagnosis of interstitial pneumonia [11], was conducted in only 5 out of the 15 cases. In addition, serum KL6 [12], which is the best marker to diagnose intestinal pneumonia, was examined in only 2 cases, including our case.

Interstitial pneumonia resolved spontaneously in our case after the discontinuation of the drug without the administration of steroids. However, there are some patients who received steroid therapy [4].

When dry cough appears in the course of the administration of DAAs, including ombitasvir/paritaprevir/ritonavir, interstitial pneumonia must be suspected immediately and prompt examination with chest $x$-ray and chest computed tomography are necessary.

\section{Conclusion}

We must pay careful attention to the development of interstitial pneumonia when dry cough appears during the treatment of HCV-associated liver diseases with oral DAAs including ombitasvir/paritaprevir/ritonavir, especially when the patient is elderly (over 70 years old). When dry cough appears, prompt examination with chest x-ray and computed tomography as well as estimation of the serum KL-6 level are recommended.

\section{Statement of Ethics}

The authors have no ethical conflicts to disclosure. Informed consent was obtained from the patient for being included in this report. This study was approved by the Medical Ethics Committee on Human Research of the Kanagawa Cancer Center.

\section{Disclosure Statement}

The authors have no conflicts of interest to declare.

\section{References}

1 Chayama K, Takahashi S, Toyota J, Karino Y, Ikeda K, Ishikawa H, Watanabe H, McPhee F, Hughes E, Kumada H: Dual therapy with the NS5A inhibitor BMS-790052 and the NS3 protease inhibitor BMS650032 in HCV genotype 1b-infected null responders. Hepatology 2012;55:742-748.

$\checkmark 2$ Kumada H, Suzuki Y, Ikeda K, Toyota J, Chayama K, Kawakami Y, Ido A, Yamamoto K, Takaguchi K, Izumi N, Koike K, Takehara T, Kawada N, Sata M, Miyagoshi H, Eley T, McPhee F, Damokosh A, Ishikawa H, Hughes E: Daclatasvir plus asunaprevir for chronic HCV genotype $1 \mathrm{~b}$ infection. Hepatology 2014;59:2983-2991.

-3 Afdhal N, Zeuzem S, Kwo P, Chojkier M, Gitlin N, Puoti M, Romero-Gomez M, Zarski JP, Agarwal K, Buggisch P, Foster GR, Brau N, Buti M, Jacobson IM, Subramanian GM, Ding X, Mo H, Yang JC, Pang PS, 


\section{Case Reports in Gastroenterology} \begin{tabular}{l|l}
\hline Case Rep Gastroenterol 2017;11:369-376 \\
\hline DOI: $10.1159 / 000462965$ & $\begin{array}{l}\text { C } 2017 \text { The Author(s). Published by S. Karger AG, Basel } \\
\text { www.karger.com/crg }\end{array}$
\end{tabular}

Tarao and Yamada: An HCV-Associated Cirrhotic Patient Developing Interstitial

Pneumonia during Antiviral Therapy with Ombitasvir/Paritaprevir/Ritonavir

Symonds WT, McHutchison JG, Muir AJ, Mangia A, Marcellin P; ION-1 Investigators: Ledipasvir and sofosbuvir for untreated HCV genotype 1 infection. N Engl J Med 2014;370:1889-1898.

-4 Mizokami M, Yokosuka O, Takehara T, Sakamoto N, Korenaga M, Mochizuki H, Nakane K, Enomoto H, Ikeda F, Yanase M, Toyoda H, Genda T, Umemura T, Yatsuhashi H, Ide T, Toda N, Nirei K, Ueno Y, Nishigaki Y, Betular J, Gao B, Ishizaki A, Omote M, Mo H, Garrison K, Pang PS, Knox SJ, Symonds WT, McHutchison JG, Izumi N, Omata M: Ledipasvir and sofosbuvir fixed-dose combination with and without ribavirin for 12 weeks in treatment-naive and previously treated Japanese patients with genotype 1 hepatitis C: an open-label, randomised, phase 3 trial. Lancet Infect Dis 2015;15:645-653. Chayama K, Notsumata K, Kurosaki M, Sato K, Rodrigues L Jr, Setze C, Badri P, Pilot-Matias T, Vilches RA, Kumada H: Randomized trial of interferon - and ribavirin - free ombitasvir/paritaprevir/ritonavir in treatment-experienced hepatitis C virus-infected patients. Hepatology 2015;61:1523-1532. Kumada H, Chayama K, Rodrigues L Jr, Suzuki F, Ikeda K, Toyoda H, Sato K, Karino Y, Matsuzaki Y, Kioka K, Setze C, Pilot-Matias T, Patwardhan M, Vilchez RA, Burroughs M, Redman R: Randomized phase 3 trial of ombitasvir/paritaprevir/ritonavir for hepatitis $C$ virus genotype $1 \mathrm{~b}$-infected Japanese patients with or without cirrhosis. Hepatology 2015;62:1037-1046. 2007;50:405-411. Camus P, Fanton A, Bonniaud P, Camus C, Foucher P: Interstitial lung disease induced by drugs and radiation. Respiration 2004;71:301-326. Child CG: The Liver and Portal Hypertension. MPCS. Philadelphia, Saunders, 1964, p 50.

10 Pugh PNH, Murray-Lyon IM, Dawson JL, Pietroni MC, Williams R: Transection of the oesophagus for bleeding oesophageal varices. Br J Surg 1973;60:646-649.

11 Cleverley JR, Screaton NJ, Hiorns MP: Drug-induced lung disease: high-resolution CT and histological findings. Clin Radiol 2002;57:292-299.

-12 Ohnishi H, Yokoyama A, Yasuhara Y, Watanabe A, Naka T, Hamada H, Abe M, Nishimura K, Higashi J, Ikezoe J, Kohno N: Circulating KL-6 levels in patients with drug induced pneumonitis. Thorax 2003;58:872-875.

13 Postmarketing surveillance of daclatasvir/asunaprevir in Japan. Page 3 (from September 3, 2014 to March 2, 2015).

14 Postmarketing surveillance of sofosbuvir/ledipasvir in Japan. Page 8 (from September 1, 2015 to February 2, 2016).

15 Postmarketing surveillance of ombitasvir/paritaprevir/ritonavir in Japan. Page 13, 17 (from November 26, 2015 to May 27, 2016). 


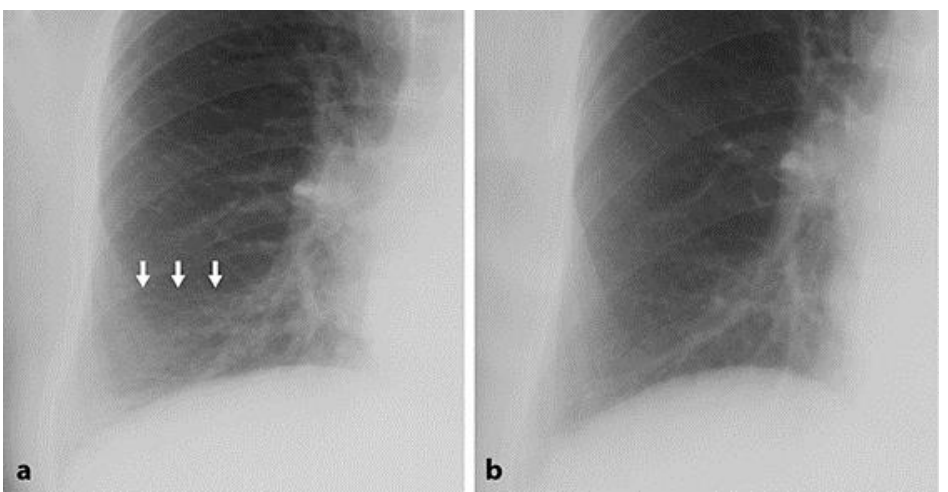

Fig. 1. Chest x-ray, 10 days after the beginning of dry cough, showed a ground-glass density in the lower part of the lung. The white arrows (a) show the lesion of interstitial pneumonia, which had almost disappeared 4 weeks after stopping the administration of ombitasvir/paritaprevir/ritonavir (b).
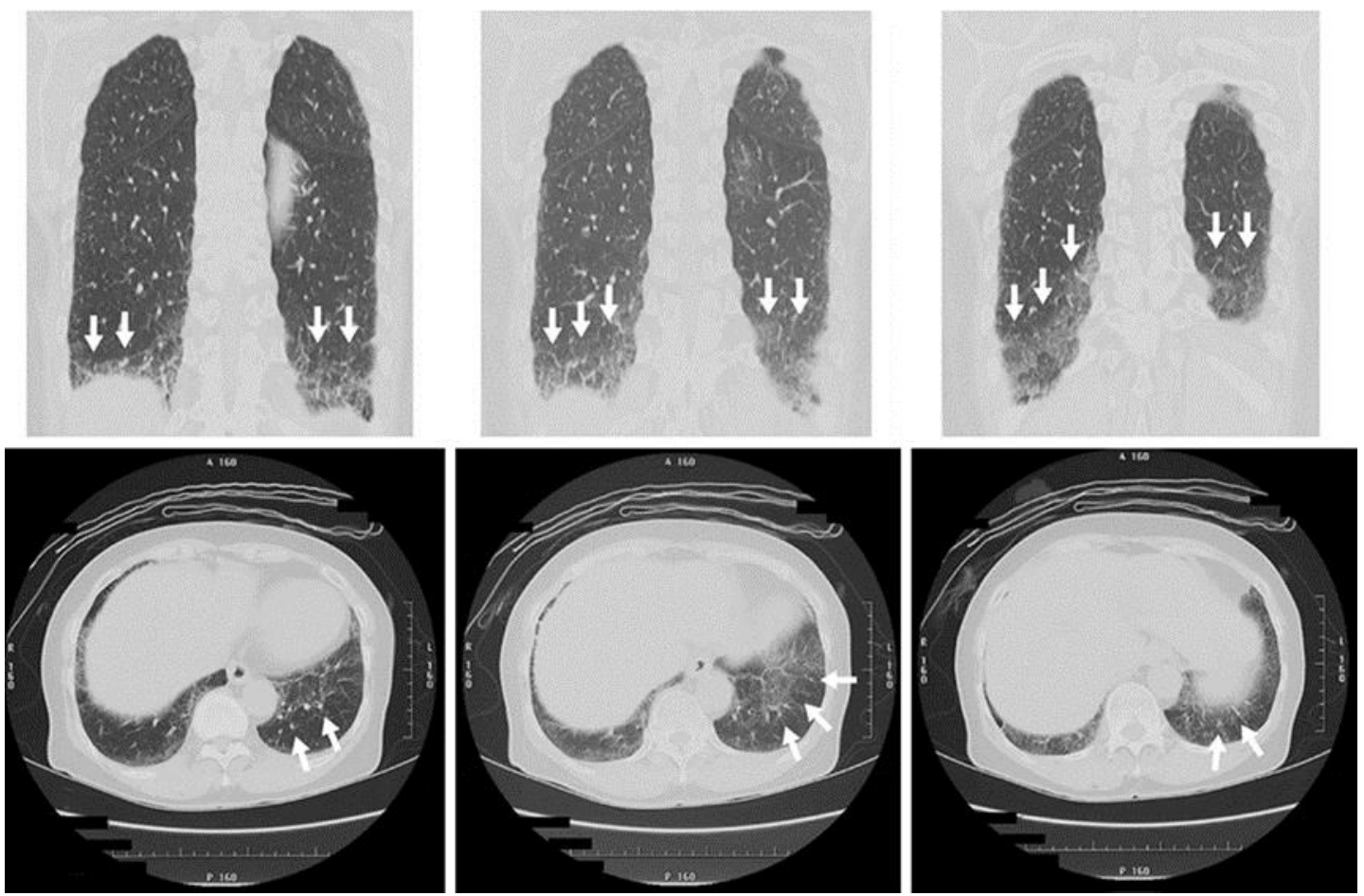

Fig. 2. Chest computed tomography showed typical features of interstitial pneumonia in the lower part of both lungs 18 days after the beginning of dry cough in both coronary (above) and sagittal (below) slices. The white arrows show the lesions of interstitial pneumonia. 

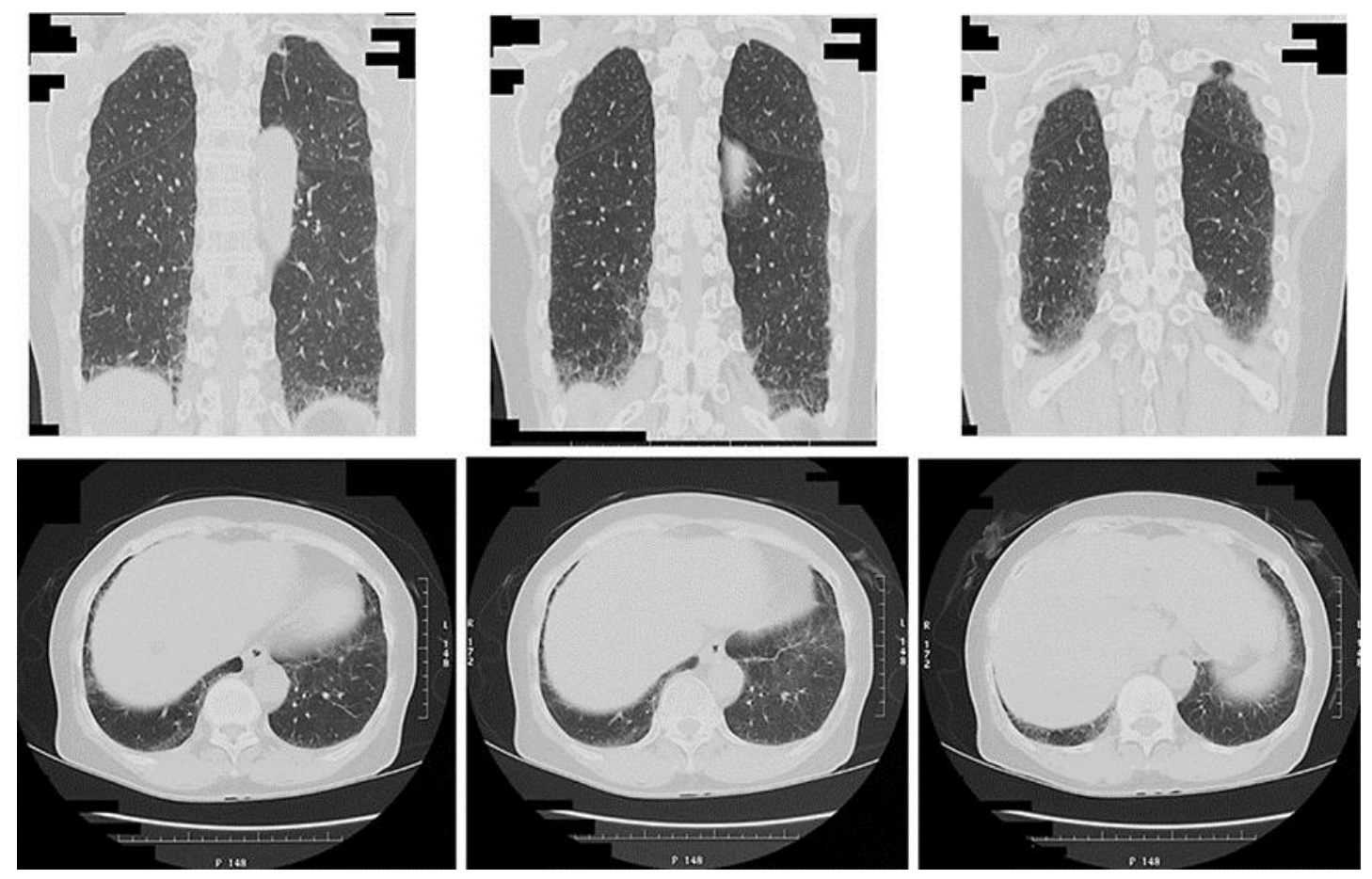

Fig. 3. Chest computed tomography on August 19 (70 days after stopping the ombitasvir/paritaprevir/ritonavir) showed marked improvement of interstitial pneumonia in both coronary (above) and sagittal (below) slices. 
Tarao and Yamada: An HCV-Associated Cirrhotic Patient Developing Interstitial

Pneumonia during Antiviral Therapy with Ombitasvir/Paritaprevir/Ritonavir

Table 1. Laboratory data at the beginning of the therapy and at the occurrence of interstitial pneumonia

\begin{tabular}{|c|c|c|}
\hline & $\begin{array}{l}\text { At the } \\
\text { beginning } \\
\text { of therapy }\end{array}$ & $\begin{array}{l}\text { At the occurrence } \\
\text { of interstitial } \\
\text { pneumonia }\end{array}$ \\
\hline \multicolumn{3}{|l|}{ Peripheral blood } \\
\hline WBC & 4,720 & 8,030 \\
\hline $\mathrm{RBC}, \times 10^{4}$ & 428 & 415 \\
\hline $\mathrm{Hb}, \mathrm{g} / \mathrm{dL}$ & 11.9 & 12.0 \\
\hline $\mathrm{Ht}, \%$ & 36.7 & 36.0 \\
\hline PLT, $\times 10^{4}$ & 15.7 & 23.6 \\
\hline \multicolumn{3}{|l|}{ Coagulation } \\
\hline PT, \% & 70.1 & 70.2 \\
\hline PT-INR & 1.20 & 1.18 \\
\hline \multicolumn{3}{|l|}{ Blood chemistry } \\
\hline $\mathrm{TP}, \mathrm{g} / \mathrm{dL}$ & 7.6 & 8.0 \\
\hline Alb, g/dL & 3.3 & 3.3 \\
\hline T-Bil, mg/dL & 0.6 & 1.3 \\
\hline AST, U/L & 101 & 25 \\
\hline ALT, U/L & 50 & 11 \\
\hline LDH, U/L & 190 & 186 \\
\hline ALP, U/L & 419 & 433 \\
\hline$\gamma$-GTP, U/L & 68 & 24 \\
\hline $\mathrm{Cr}, \mathrm{mg} / \mathrm{dL}$ & 0.74 & 0.80 \\
\hline T-cho, mg/dL & 122 & 120 \\
\hline Glu, mg/dL & 112 & - \\
\hline \multicolumn{3}{|l|}{ Viral markers } \\
\hline HBs-antigen & $(-)$ & - \\
\hline $\mathrm{HCV}-\mathrm{Ab}$ & $(+)$ & / \\
\hline HCV-RNA, $\log _{10} \mathrm{IU} / \mathrm{mL}$ & 6.5 & $(-)$ \\
\hline HCV genotype & (1) & / \\
\hline IL28B & TT & / \\
\hline \multicolumn{3}{|l|}{ Tumor marker } \\
\hline AFP, ng/mL & 13.4 & 3.9 \\
\hline $\mathrm{KL}-6, \mathrm{U} / \mathrm{mL}$ & - & $1,036(1,180)$ \\
\hline
\end{tabular}

Table 2. Interstitial pneumonia caused by oral DAAs

Number of cases

(fatal cases)

1 Asunaprevir/daclatasvir

2 Sofosbuvir/ledipasvir

3 Sofosbuvir/ribavirin

4 Ombitasvir/paritaprevir/ritonavir
$4(0)$

5 (1)

2 (1)

4 (1) 